\title{
Aristolochia maxima (Aristolochiaceae): A new record for India
}

\author{
A.G. Pandurangan* and S. Deepu \\ Jawaharlal Nehru Tropical Botanic Garden and Research Institute, Karimancode P.O., Thiruvananthapuram, \\ Kerala - 695 562, India. \\ *Email: agpandurangan@gmail.com
}

\begin{abstract}
Aristolochia maxima is a Neotropical species native to Central and South America. It is reported here for the first time from northern Western Ghats of Maharashtra, India. A brief description along with photographs are provided for easy identification.
\end{abstract}

Keywords: India, Maharashtra, Taxonomy, Neotropical.

\section{Introduction}

Aristolochia L., the largest genus of the family Aristolochiaceae, comprises c. 500 species, is pantropically distributed, extending to the subtropics as well as to Mediterranean zones with a few species in temperate areas (Pfeifer, 1966; Wagner et al., 2012; Do \& Nghiem, 2017). Diversity of the species declines sharply from tropics to temperate regions with China, Mexico, Brazil, and Hispaniola showing high rate of endemism (Pfeifer, 1966; González et al., 2014; Do \& Nghiem, 2017). In India, the genus is represented by 18 species (Santapau \& Henry, 1973; Sivarajan \& Pradeep, 1989; Karthikeyan et al., 2009; Baruah et al., 2012; Ravikumar et al., 2014). During the field exploration to northern Western Ghats in 2013, an unreported species of Aristolochia was collected from Tilari Ghats of Maharashtra. On careful examination, it was identified as Aristolochia maxima Jacq., which is reported here as new to India.

\section{Taxonomy}

Aristolochia maxima Jacq., Enum. Syst. Pl. 30, 1760. Neotype, (designated by Howard, 1988): Jacq., Select. Stirp. Amer. Hist. t. 146. (1763).

Figs. 1 \& 2.

Sprawling lianas, c. $20 \mathrm{~m}$ long, stem at base woody with corky-ridged bark. Leaves oblong to obovate, $6-11.3 \times 2.6-5 \mathrm{~cm}$, obtuse to apiculate at apex, truncate to shallowly subcordate at base, with prominent, raised veins beneath; petioles c. 1.6 $\mathrm{cm}$ long. Inflorescences on new growth, axillary, solitary flowers or rhipidiate from base of plant; flowers puberulent, bracteolate, geniculate, purple

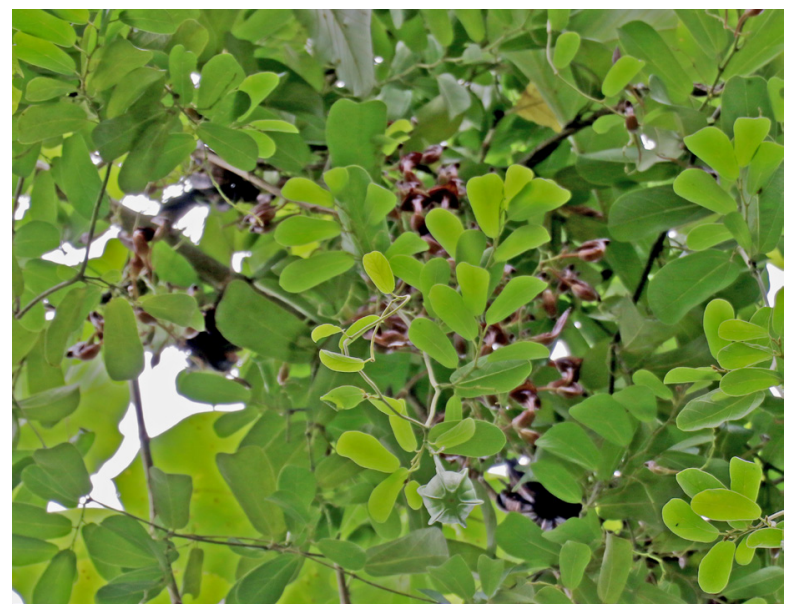

Fig. 1. Aristolochia maxima Jacq. in flowering and fruiting.

brown with venaceous veins; the utricle horizontal, ovoid, 2-2.5 cm long, creamy white with reddish brown patches, stellate hairy, reddish brown ring towards the base; syrinx absent; the tube bent, $2 \mathrm{~cm}$ long, the limb 1 lobed, ovate, gradually expanding from the tube with dense papillae, $2.5-3.5 \mathrm{~cm}$ long, 2-3 cm wide. Gynostemium 6 lobed, $4-5 \times 4 \mathrm{~mm}$, crown-shaped; lobes acute to obtuse. Anthers 6, oblong, adnate to the base of the gynostemium, each anther consists of two thecae with four microsporangia (pollen sacs) equidistant. Ovary 6 locular, $2-2.5 \mathrm{~cm}$ long. Fruits very large, pendent, ovoid, 14-17 × 6-7 cm, dehiscence acropetal, septifragal, exposing latticed septa, hypanthium absent. Seeds numerous, flat, triangular, 10-13 × 7-9 mm, $1 \mathrm{~mm}$ thick.

Flowering \& fruiting: March-August. 


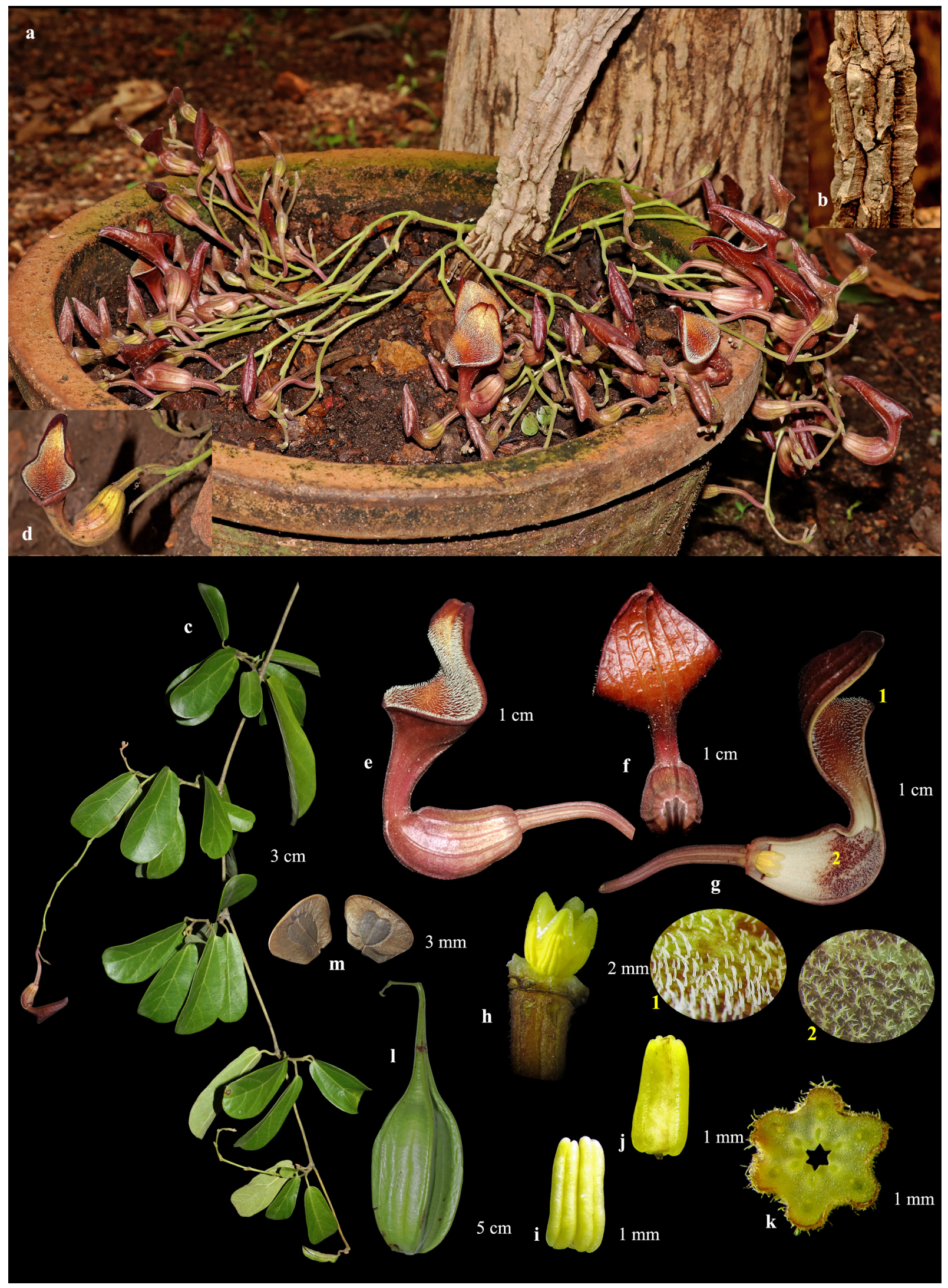

Fig. 2. Aristolochia maxima Jacq. a.\& b. Corky stem; c. Flowering twig; d. Flower; e. Flower side view; f. Flower back view; g. Flower with calyx coloum open (1. Unicellular hairs in the limb, 2. Stellate hairs inside the utricle); h. Gynostemium; i. Stamens: front view; j. Stamens: back view; k. C.S. of ovary; I. Fruit; $\mathbf{m}$. Seeds. 
Distribution: Central, North and South America, Martinique. In India it is found growing on moist thickets at an elevation of c. $590 \mathrm{~m}$ along northern Western Ghats in Maharashtra.

Notes: This species is commonly known as Florida Dutchman's pipe vine and is distributed in the Neotropical regions and its present report is of phytogeographical significance as may be a case of escape into wild. Pollination systems of A. maxima are different from those of other Aristolochia in lacking trap mechanisms. Furthermore, the pollinators oviposit in the flowers, and their larvae grow on the fallen, decaying flowers on the ground. Therefore, the plants have a mutualistic relationship with their pollinators (Sakai, 2002). Preliminary observations show that even though there is profuse fruiting and seed setting, the regeneration rate is quite low.

Specimens examined: INDIA, Maharashtra, Kolhapur district, Tilari Ghats, 15.10.2013, A.G. Panduragan E Deepu Sivadas 78664 (TBGT!).

\section{Literature Cited}

Baruah, S., Sarma, J. \& S.K. Borthakur 2012. Aristolochia planifolia (Koltz.) Duch. (Aristolochiaceae): A new record for Assam, India. Asian J. Cons. Biol. 1(2): 138-139.

Do, T.V. \& T.D. Nghiem 2017. Taxonomic notes on some Aristolochia species in Vietnam. Taiwania 62(2): 216-218. http://dx.doi.org/10.6165/tai. 2017.62.216.

González, F., Wagner, S.T., Salomo, K., Symmank, L., Samain, M.S., Isnard, S., Rowe, N.P., Neinhuis, C. \& S. Wanke 2014. Present transPacific disjunct distribution of Aristolochia subgenus Isotrema (Aristolochiaceae) was shaped by dispersal, vicariance and extinction. J. Biogeogr. 41: 380-391.

Howard, R.A. 1988. Aristolochiaceae. Fl. Lesser Antilles 4: 120-126.
Karthikeyan, S., Sanjappa, S. \& S. Moorthy 2009. Flowering Plants of India - Dicotyledons. Vol. 1 (Acanthaceae - Avicenniaceae). Botanical Survey of India, Kolkata.

Pfeifer, H.W. 1966. Revision of the North and Central American hexandrous species of Aristolochia (Aristolochiaceae). Ann. Missouri Bot. Gard. 53: 115-196.

Ravikumar K., Umeshkumar, T. \& N. Balachandran 2014. Aristolochia gurinderii (Aristolochiaceae): a new species from Great Nicobar Island, India. Phytotaxa 172(2): 117-122. http://dx.doi.org/10.11646/phytotaxa.172.2.7

Sakai, S. 2002. Aristolochia spp. (Aristolochiaceae) pollinated by flies breeding on decomposing flowers in Panama. American J. Bot. 89(3): 527534. http://dx.doi: 10.3732/ajb.89.3.527

Santapau, H. \& A.H. Henry 1973. A Dictionary of the Flowering Plants in India. Publication and Information Directorate-CSIR, New Delhi.

Sivarajan, V.V. \& A.K. Pradeep 1989. A new species of Aristolochia (Aristolochiaceae) from India with co-evolutionary notes on $A$. indica and papilionoid butterfly. Plant Syst. \& Evol. 163: 31-34. http://dx.doi.org/10.1007/ bf00936150

Wagner, S.T., Isnard, S., Rowe, N.P., Samain, M.S., Neinhuis C. \& S. Wanke 2012. Escaping the lianoid habit: evolution of shrub-like growth forms in Aristolochia subgenus Isotrema (Aristolochiaceae). American J. Bot. 99(10): 1609-1629.

Received: 21.11.2017

Revised and Accepted: 27.12.2018 